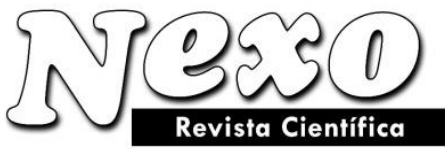

Vol. 34, No. 02, pp. 950-963/Junio 2021

\title{
Challenges and prospects of the fishing export potential development in the Far East
}

\section{Retos y perspectivas del desarrollo potencial de las exportaciones pesqueras en el Lejano Oriente}

\author{
Andrey G. Paptsov ${ }^{1, *}$, Nadejda A. Shelamova ${ }^{1}$, Nabi D. Avarskii ${ }^{1}$, Khatimat N. Gasanova ${ }^{1}$, Kirill \\ V. Kolonchin ${ }^{2}$, Oleg I. Betin ${ }^{2}$ \\ ${ }^{1}$ Federal State Budgetary Scientific Institution, "Federal Research Center of Agrarian Economy and \\ Social Development of Rural Areas - All-Russian Research Institute of Agricultural Economics" under \\ Ministry of Science and Higher Education of Russian Federation, Moscow, Russian Federation \\ ${ }^{2}$ Federal State Budget Scientific Institution "All-Russian Scientific Research Institute of Fisheries and \\ Oceanography” (VNIRO), Moscow, Russian Federation. \\ *a.g.paptsov@vniiesh.ru
}

(recibido/received: 05-febrero-2021; aceptado/accepted: 05-abril-2021)

\begin{abstract}
According to the objectives of the federal project "Export of Agribusiness Products", the Far Eastern Federal District (FEFD) should increase the export of aquatic biological resources (ABR), including fish, to USD 1,338 million by 2024. Fish and fish products are among the top three agricultural exports in Russia (along with grains and oilseeds). The Far East is the main region in the Russian Federation for the capture of fish and other ABR. The article deals with the indicators of production and export of ABR of the fisheries industry of the FEFD, which includes also the Kamchatka Territory, Primorsky Territory, and the Sakhalin region. The authors consider problems that hinder its effective development and analyze directions and measures to solve existing problems. The main negative factors are associated with the infrastructural shortcomings, such as physical and moral deterioration of the fishing fleet, the lack of modern processing facilities, which do not allow producing fish products with high added value in the proper amount. To develop the concerned industry sector and resolve the issues constraining the growth of production and export capacity in the entities of the FEFD, the Russian government has developed special programs to promote investment activity, the construction of the necessary fishing fleet and infrastructure facilities, and modernization of existing facilities.
\end{abstract}

Keywords: Fish; Aquatic biological resources; Fisheries industry; Aquaculture; Infrastructure; State support.

\section{RESUMEN}

De acuerdo con los objetivos del proyecto federal "Exportación de productos agroindustriales", el Distrito Federal del Lejano Oriente (FEFD) debería aumentar la exportación de recursos biológicos acuáticos (ABR), incluido el pescado, a USD 1338 millones para 2024. El pescado y los productos pesqueros son 
entre las tres principales exportaciones agrícolas de Rusia (junto con los cereales y las semillas oleaginosas). El Lejano Oriente es la principal región de la Federación de Rusia para la captura de peces y otros ABR. El artículo trata de los indicadores de producción y exportación de ABR de la industria pesquera del FEFD, que incluye también el Territorio de Kamchatka, el Territorio de Primorsky y la región de Sakhalin. Los autores consideran problemas que dificultan su eficaz desarrollo y analizan orientaciones y medidas para solucionar los problemas existentes. Los principales factores negativos están asociados a las deficiencias de infraestructura, como el deterioro físico y moral de la flota pesquera, la falta de modernas instalaciones de procesamiento, que no permiten producir productos pesqueros con alto valor agregado en la cantidad adecuada. Para desarrollar el sector industrial en cuestión y resolver los problemas que limitan el crecimiento de la capacidad de producción y exportación en las entidades de la FEFD, el gobierno ruso ha desarrollado programas especiales para promover la actividad inversora, la construcción de la flota pesquera y las instalaciones de infraestructura necesarias, y la modernización de las instalaciones existentes.

Palabras claves: Pez; Recursos biológicos acuáticos; Industria pesquera; Acuicultura; Infraestructura; Apoyo estatal.

\section{INTRODUCTION}

Since 2018, Russia has been implementing the federal project "Export of agribusiness products", whose purpose is to stimulate agricultural exports. The main objectives of the project are to create a new marketable mass of agricultural products, including products with high added value, through technological re-equipment of the industry and other supporting measures, as well to develop an export-oriented commodity distribution infrastructure. A significant role in the project is assigned to the development of the country's fisheries industry.

The fishing industry plays an important role in the economy of the Russian Federation since it solves the problems of ensuring food security, economic growth of the country, strengthening its export potential, as well as the socio-economic development of the regions.

Globally, the Russian Federation is among the top five world leaders in terms of production (catch) of fish and other ABR, which allows it to compete quite successfully with other countries in international markets. In terms of certain product categories, Russia occupies a leading position in global production volumes (by catching cod $-29 \%$, salmon $-52 \%$, herring $-4.3 \%$ ) (Order of the Government of the Russian Federation, 2019). The FEFD is the most important fishing area of Russia, as well as the largest exporter.

In the agribusiness of Russia, fish and other ABR are the main export products along with grains and oilseeds.

\section{LITERATURE REVIEW}

Foreign economic activity is an integral part of the state's economy. International trade encourages the mobilization and more effective use of the potential of any country, contributes to the growth of labor productivity and income. Development of trade in agricultural products and increase of export potential are one of the most important directions of the agricultural policy of the Russian Federation. To date, there is no well-established definition of the concept of "export potential". The authors of the present research adhere to the definition given by Yu.A. Savinov and A.Yu. Migunov (2008), who interpret export potential as the ability of the economy, its sectors, industries, enterprises, and companies to produce goods and services that are competitive on the world market, using existing comparative national advantages or new competitive advantages based on the achievements of science and scientific and technological 
progress. Export activities, both for the entire state and an individual enterprise or industry, provide the following opportunities: improving the efficiency of using natural resources; increasing foreign exchange earnings and replenishing the budget; increasing the level of employment of the population; stimulating the economic growth of the country and improving the level and quality of life of the population.

The scientific and theoretical basis of the study includes the classical theories of international trade, namely:

- Adam Smith's theory of absolute advantages, according to which a country that can produce a particular product in greater quantity and cheaper than other countries due to certain conditions, has an absolute advantage. The author has noted that exports are a positive factor for the country's economy, ensuring the sale of surplus products.

- David Ricardo's theory of comparative advantages, according to which specialization in the production of a product that has the maximum comparative advantages, is beneficial even in the absence of absolute advantages;

- Michael Porter's theory. This theory introduces the concept of a country's competitiveness. It is national competitiveness, from Porter's point of view, that determines success or failure in specific industries and the place that a country occupies in the world economy. Competition stimulates the development of innovative activities in various sectors of the economy.

The present study also relies on legal and policy documents regulating foreign trade activities of the Russian Federation, in particular: Federal Law "State Regulation of Foreign Trade Activity" (December 8, 2003), Federal Law "On Measures for Protection of Economic Interests of the Russian Federation in Carrying out Foreign Trade in Goods" (April 14, 1998), the State program "Development and Regulation of Farm Produce, Raw Materials and Foodstuffs Markets for 2013-2020" (Resolution of the Government of the Russian Federation, July 14, 2012).

The issues of state support for the development of export activities in the agricultural sector are discussed in the works of several scientists of the Federal State Budgetary Scientific Institution "Federal Research Center of Agrarian Economy and Social Development of Rural Areas - All-Russian Research Institute of Agricultural Economics", in particular, I.G. Ushachev (2019), A.G. Paptsov, A.I. Altukhov, V.V. Maslova (2020), N.A. Medvedeva (2019), and others. The noted studies formulate the main paths for the successful increase in the export of agricultural products and food for the Russian agribusiness, grouped into four blocks: 1) improving the efficiency of the use of national resources, increasing the volume of agricultural production, and improving the competitiveness of Russian agricultural products; 2) greening and ensuring the safety of agricultural products and food; 3) ensuring the accelerated development of logistics in agriculture; 4) supporting export and expanding its access to international markets.

The development of export potential implies the improvement of export infrastructure, including the Russian fisheries sector. Fish products and other ABR are some of the main export products of the Russian agribusiness. Studies of the challenges and development tendencies of export potential and infrastructure of the Russian fisheries industry and, in particular, the Far East are presented in the scientific work of many researchers, among them O.Yu. Vorozhbit (2007), V.I. Ivanova (2011), S.M. Ryzhkova (2020), N.D. Avarsky, N.A. (2015), Shelamova (2020), K.V. Kolonchin $(2018,2019)$ and S.N. Seregin (2018). The works assess the status of the Russian fisheries industry components, namely, the fishing fleet, storage, and processing infrastructure, and personnel support. The authors consider the main development problems, including the predominance of raw materials in the export of ABR, a low share of products with high added value, and their low competitiveness, limited access to financial instruments to 
support the industry, the inability to attract long-term financing on acceptable terms, and underfunding of science.

When studying the development problems and prospects of the Far East fisheries industry, in addition to the above-noted works, the authors relied on the "Strategy for Development of Agriculture and Fisheries of the Russian Federation through 2030" (Order of the Government of the Russian Federation, 2019), annual reports, and policy documents of the FEFD, which indicate basic lines of development of export potential and improvement of infrastructure in the fisheries industry of the region.

\section{PROPOSED METHODOLOGY. GENERAL DESCRIPTION}

The research object was the fisheries industry of the FEFD and its main fishing zones, namely, the Primorsky Territory, Kamchatka Territory, and the Sakhalin region. The research subject was the development problems and prospects of the export potential and fishing infrastructure of the FEFD. Sources of economic, scientific, and technical information included the works of Russian and foreign scientists, data of Federal State Statistics Service (Rosstat), the "State Program on Development and Regulation of Farm Produce, Raw Materials and Foodstuffs Markets", "Strategy for Development of Agriculture and Fisheries of the Russian Federation through 2030", as well as regional programs and annual reports of the FEFD fisheries industry.

\section{ALGORITHM}

Economic and statistical data processing was carried out using generally accepted methods of economic analysis. The following research methods were used to analyze the current state, problems, and trends in the development of the fisheries industry of the FEFD, including the Primorsky Territory, Kamchatka Territory, and the Sakhalin region: monographic, economic and statistical methods, expert assessment method, as well as synthesis, and analysis. Based on the conducted research, suggestions have been given regarding the possibilities of increasing the export potential and developing the fishing infrastructure in the Far East.

\section{RESULTS}

In 2019, more than 4.92 million tons of fish and other ABR were caught in the country, which was $2.2 \%$ less than in 2018, when the record catch rate for the last 26 years was reached, amounting to 5.1 million tons. In the period from 2009 to 2018, the volume of production (catch) of ABR increased by more than one million tons or $34 \%$. By 2024, it is projected to increase production to 5.4 million tons per year.

In the structure of agri-food exports of Russia, fish and seafood are in third place. From 2011 to 2018, the export of these products increased 1.8 times. The federal project "Export of Agribusiness Products" provides for the achievement of the fish and seafood exports volume of USD 8.5 billion by the end of 2024.

According to Rosstat, the volume of the Russian export of fish products in 2018, when a record level was achieved, increased by $4.5 \%$ in physical terms, compared to 2017, and amounted to 2,237 thousand tons (excluding food fish products); in monetary terms, it increased by 17\% and amounted to USD 5,174 million. In the total export structure of fish products, the share of frozen fish was $87 \%(1,956$ thousand tons) or USD 3,249 million (63\%) (Table 1). Crustaceans and shellfish are also important export products, whose proportion was 126.5 thousand tons $(5.6 \%)$ or USD 1,320 million $(25 \%)$ in natural terms. 
Table 1. Fish and other products exports structure in Russia in 2018

\begin{tabular}{|c|c|c|c|c|}
\hline Indicators & $\begin{array}{l}\text { In physical } \\
\text { terms, } \\
\text { thousand tons }\end{array}$ & $\begin{array}{l}\% \text { of the } \\
\text { total } \\
\text { volume }\end{array}$ & $\begin{array}{l}\text { In value terms, } \\
\text { USD million }\end{array}$ & $\begin{array}{l}\% \text { of the } \\
\text { total volume }\end{array}$ \\
\hline Frozen fish & $1,956.0$ & 87 & 3,249 & 63 \\
\hline Fillet of frozen fish, minced fish & 124.0 & 5.5 & 503 & 10 \\
\hline Live, fresh, chilled fish & 5.4 & 0.2 & 5.9 & 0.1 \\
\hline Canned fish products & 19.0 & 0.8 & 64 & 1.2 \\
\hline $\begin{array}{l}\text { Crustaceans, mollusks, and other } \\
\text { invertebrates }\end{array}$ & 126.5 & 5.6 & 1,320 & 25 \\
\hline
\end{tabular}

Source: Compiled by the authors according to the data retrieved from the Ministry of Agriculture of Russia (Savinov and Migunov, 2008; Federation Council of the Federal Assembly of the Russian Federation, 2019)

The data shown in Table 1 indicate that the Russian export includes mainly products with low added value, that is, raw products for further processing abroad. The largest countries that purchased $95 \%$ of Russian fish products in 2018, according to the Federal Customs Service of Russia, were China, whose share amounted to $40.9 \%$ (in value terms), the Republic of Korea $-24.8 \%$, the Netherlands $-13.6 \%$, and Japan - 9.0\% (Federal law of the Russian Federation, 2003; Sea News, 2019).

In terms of the fish and seafood caught in Russia, the superiority belongs to the seas of the Pacific Ocean, surrounding the Far Eastern region of the country, namely the Bering, Okhotsk, and Japanese seas, reach with the world's largest stocks of salmon (chum, sockeye, and Chinook salmon), as well as cod species (cod, pollock, saffron cod, and hake). The region is a habitat of crab, seals, walruses, fur seals, and more than two thousand species of various hydrobionts. Supply of ABR of the Far Eastern basin amounts to 26 million tons and can provide fish and seafood caught in the amount of three million tons per year. The Far East accounts for almost 2/3 of the total fish caught in Russia. The largest volume of fish production in the FEFD is accounted for by codfish species (pollock and cod), whose share is approximately $70 \%$. This figure differs slightly in different years. The average annual pollock catch in the region over the past three years was approximately 1.7 million tons. Salmon and herring also account for a significant share of fish production in the region.

In 2018 (the record year for the ABR catch in Russia), the main volume of fish caught traditionally fell on the Far Eastern fisheries basin amounting to 3.5 million tons, which was by $11 \%$ more than that in 2017 . More than 676 thousand tons of Pacific salmon were produced, which was more than twice the figure of 2017, including 509 thousand tons of pink salmon and 81 thousand tons of chum salmon. This was the maximum amount of salmon caught in the entire history of observations (Federal law of the Russian Federation, 1998; Kuban Agricultural Information and Consulting Center, 2019).

In 2019, the Far Eastern region traditionally made the largest contribution to the all-Russian production of ABR in marine waters $-69.6 \%$ of the total catch in Russia, or 3,424.79 thousand tons. The main volume of production fell on pollock - 1,733 thousand tons (103\% to the level of 2018). The catch of herring amounted to 384 thousand tons (104\% to 2018), cod - 156 thousand tons (125\%), and crabs -72 thousand tons (95\%) (Resolution of the Government of the Russian Federation, 2012; Public Council at the Federal Agency for fishery, 2020).

Of particular note is the crab harvest. Commercial species of crabs inhabit mainly the seas of the Pacific Ocean, namely, the Far East (in the areas of the Okhotsk and Bering Seas), the coast of Alaska, as well as some areas of the Atlantic and Indian Oceans. Due to the limited distribution areas and low population level, the number of countries that produce and supply crab products to the world market is small. These are Russia, Japan, the USA, and Canada. Small volumes of crabs are also produced by Vietnam, India, Indonesia, and Malaysia. 
In the Far East, nine subspecies of crabs are fished, of which the main ones being the Kamchatka crab (Russian or royal), it accounts for about $40 \%$ of the total catch of crabs, as well as the snow crab (about $30 \%)$, and the blue crab (5-9\%).

Russia is the largest producer and exporter of crab (various species), whose volume in world supplies from the country is $63 \%$. The most prized is the king crab ${ }^{1}$. Russia's share in the global king crab market is approximately $45 \%$. For comparison, the share of the USA (Alaska), the second-largest region exporting king crab, in world trade is about $15 \%$.

Crab products, along with salmon and sturgeon caviar, are considered a delicacy. They are characterized by special taste qualities, high price, and are in steady demand in the world market. For Russia, the production of crabs is one of the permanent items of income from exports.

The Far East is not only the main fishing region of Russia but also the largest exporter. In the regional structure of the FEFD, the Primorsky Territory, Kamchatka Territory, and the Sakhalin region are leaders in the export of fish and seafood. In terms of the cost of exported fish products, the Primorsky Territory is a leader, while the Kamchatka Territory is in second place. The commodity structure of exports consists of $88 \%$ of frozen fish, about $6 \%$ of fish fillet and other fish meat, $5 \%$ of crustaceans, mollusks, and other aquatic invertebrates, and $1 \%$ of finished or canned fish products.

Exports of fish and other ABR in the FEFD for the first nine months of 2019 amounted, according to the Far Eastern Customs Administration, to 1.2 million tons worth USD 2.6 billion. The main importers of Far Eastern fish and other products are China, the Republic of Korea, and Japan. For nine months of 2019, 822 thousand tons $(70 \%)$ were exported to China, 288 thousand tons $(24.6 \%)$ - to the Republic of Korea, and 25 thousand tons (2.3\%) - to Japan (Paptsov et al., 2020; Federation Council of the Federal Assembly of the Russian Federation, 2019; Fishretail, 2019).

\section{THE KAMCHATKA TERRITORY}

Kamchatka is rightly called the fish factory of Russia. It produces a fifth of all the products of the Russian fisheries industry. Every year, about one million tons of ABR are caught in the fishing zone of the region. These include Pacific salmon, pollock, cod, halibut, flounder, crabs, and marine invertebrates. The fishing industry plays a leading role in the economy of Kamchatka. It accounts for more than half of industrial production and $90 \%$ of the region's export potential. The region's enterprises produce about 800 thousand tons of fish products annually.

The sea area adjacent to the Kamchatka Territory is the largest fishing area in the Far Eastern region. Its total area is 1,473 thousand square kilometers or 427.5 thousand square miles. Besides, almost all rivers in the territory of Kamchatka are of fishery importance, providing a spawning fund for Pacific salmon and other fish species.

The fishing industry of the peninsula is constantly being modernized and developed. Over the past few years, 15 modern high-tech processing plants have been built on the coast, and almost two thousand new jobs have been created. In the development of the industry, the emphasis is placed on expanding the range of products, developing port infrastructure, and ship repair facilities (Ushachev et al., 2019b; Fishnews, 2020).

In 2018, the total volume of exports of fish, fish products, and seafood amounted to 304,585 tons. This was by $1.5 \%$ less than in 2017 (308.5 thousand tons). At the same time, exports in value terms increased

\footnotetext{
${ }^{1}$ Also called Kamchatka crab or Alaskan king crab
} 
by $20 \%$ and amounted to USD 797.7 million (USD 662.6 million in 2017). Figures on the export of ABR in 2018 by product type are presented in Table 2 .

Table 2. Exports structure of fish and other aquatic products in the Kamchatka Territory in 2018

\begin{tabular}{lllll}
\hline Indicators & $\begin{array}{l}\text { In physical terms, } \\
\text { thousand tons }\end{array}$ & $\begin{array}{l}\text { \% of the total } \\
\text { volume }\end{array}$ & $\begin{array}{l}\text { In value terms, USD } \\
\text { million }\end{array}$ & $\begin{array}{l}\text { \% of the total } \\
\text { volume }\end{array}$ \\
\hline Frozen fish & 278.0 & 91.2 & 640.9 & 80.3 \\
Fish flour & 11.4 & 3.7 & 12.4 & 1.6 \\
Fish fillet, minced fish & 8.5 & 2.8 & 21.6 & 2.7 \\
Crabs, shrimps & 5.8 & 1.9 & 120.8 & 15.1 \\
Shellfish & 0.7 & 0.2 & 1.2 & 0.15 \\
\hline Source: Compiled by the authors according to the data retrieved from Kamchatka Statistic Service (Kamchatstat) (Ushachev et al., 2019a; KAM 24, 2019)
\end{tabular}

One of the main tasks of the fisheries industry development is to expand the export of ABR with an emphasis on high-value products. The Ministry of Fisheries of the Kamchatka Territory, together with other federal and regional authorities, are making efforts to implement the regional project "Export of Agribusiness Products", which will increase supply of fish and other aquatic products to USD 1,234 million by 2024. In 2019, the volume of exports reached USD 837 million (128\% of the planned figure for 2019 , and $106 \%$ of the level of 2018).

The Kamchatka fisheries industry demonstrates investment activity. For the first nine months of 2019, the volume of investments in fixed assets amounted to RUB 5.6 billion, while in 2008 less than one billion extrabudgetary funds were invested. Subsidies from the regional budget were given to 15 investment projects, at that the amount of support was estimated at RUB 182 million.

To date, 14 fisheries organizations with investment projects totaling more than RUB 8 billion have received the status of residents of the priority development area (PDA) and are successfully implementing their development plans mainly for the construction and modernization of onshore production facilities. Two enterprises are implementing a program to create a hub port in Petropavlovsk-Kamchatsky, designed for comprehensive servicing of fishing vessels and organization of transshipment of refrigerated and dry container cargo. Investors are supported by the Ministry of Regional Development, as well as by the regional government.

Such projects should help in solving the problem of fish cargo delivery through the Vladivostok logistics hub. Efforts on the logistics development allowed delivering five thousand tons of fish products from Kamchatka producers to St. Petersburg from Petropavlovsk. For the first time, this happened in 2019. Today, a lot of efforts are being made by the state and business to make this line work. Turning one-time deliveries into regular cargo traffic along the Northern Sea Route through Kamchatka from the AsiaPacific region to the central part of Russia and the countries of the European Union is one of the tasks for 2020 and the near future (Ushachev et al., 2019b; Fishnews, 2020).

\section{THE PRIMORSKY TERRITORY}

In Primorye, one of the largest fisheries industries in Russia has been created, which produces $15 \%$ of all fish products in Russia, and $24 \%$ of all fish products in the Far Eastern region. The fishing industry is a key industry in the region and has great impact on the economy of both Primorye and the Far East in general.

More than 130 fisheries enterprises operate in the territory of the region. These enterprises produce about 800 thousand tons of various food fish products, as well as canned products in the amount of more than 110 million conventional cans. At that, 76 fish farms are provided with 205 fish-breeding areas with a 
total area of more than 44 thousand hectares. In these fish-breeding areas, they breed Japanese scallops, Pacific mussels, oysters, Japanese sea cucumber, laminaria, and sea urchins. Fishermen in Primorye were the first in the country to catch deep-sea resources with crab processors. Powerful modern equipment installed on the vessels allows fishing at a depth of up to 2.5 thousand meters. In 2018, Primorye enterprises produced more than 740 thousand tons of ABR, and in the first nine months of 2019, the catch amounted to more than 771 thousand tons (Table 3).

Table 3. Catch and export indicators of fish and nonfish products of fishing enterprises of the Primorsky Territory in 2017-2019, thousand tons

\begin{tabular}{|c|c|c|c|c|c|}
\hline \multirow[b]{2}{*}{ Indicators } & \multicolumn{3}{|l|}{ Years } & \multirow{2}{*}{$\begin{array}{l}2018 \text { in } \\
\% \quad \text { to } \\
2017\end{array}$} & \multirow{2}{*}{$\begin{array}{ll}2019 & \text { in } \\
\% & \text { to } \\
2018 & \end{array}$} \\
\hline & 2017 & 2018 & $2019 *$ & & \\
\hline Catch of fish and nonfish products & 762.5 & 740.3 & 771.4 & 97.1 & 104.2 \\
\hline Production of fish products, including canned fish & 702.8 & 609.7 & 664.0 & 86.8 & 108.9 \\
\hline Release of live fish, fresh and chilled fish & 31.0 & 39.4 & 56.8 & 127.1 & 143.0 \\
\hline Export deliveries & 635.1 & 760.2 & 750.4 & 119.7 & 98.7 \\
\hline Share of exports in total output, $\%$ & 86.5 & 117.1 & 104.1 & $\begin{array}{l}+30.6 \\
\text { p.p. }\end{array}$ & -13 p.p. \\
\hline Exports in value terms, USD million & 985.8 & $1,373.3$ & $1,439.1$ & 139.3 & 104.8 \\
\hline
\end{tabular}

* Results for nine months of 2019

Source: Compiled by the authors based on (Medvedeva, 2019; Official website of the Government of Primorsky Krai, 2020)

The largest export of fish and nonfish products in natural terms was recorded in 2018 and amounted to 760 thousand tons; in value terms, it was recorded in 2019 and amounted to USD 1,439 million, having increased by more than USD 65 million compared to the previous year.

According to the Russian Federal Fisheries Agency, in 2019 the proportion of the catch of ABR by enterprises of the Primorsky Territory was $22.6 \%$ of the total catch in the Far Eastern Fisheries Basin and $15.7 \%$ of the all-Russian catch. In 2019, more than half of the total catch of fish and nonfish products was pollock -435 thousand tons, in the second place was the production of herring, including West Pacific sardines (ivasi) - 90.6 thousand tons, the catch of cod was at the level of 14.7 thousand tons, of squid - at the level of 17.6 thousand tons, and of all types of crabs - at the level of 17.5 thousand tons (Resolution of the Government of the Russian Federation, 2012; Public Council at the Federal Agency for fishery, 2020). In the export structure, in value terms, more than $60 \%$ are frozen fish, while crustaceans and shellfish amount to about $20 \%$. The main importers of coastal fish and other ABR are China, the Republic of Korea, and Japan.

In the Primorsky Territory, the state program "Development of Fishery Complex in Primorsky Region for 2013-2021" was implemented. One of the subprograms of this program is the "Development of the fish products market in the Primorsky Territory". The subprogram includes the following main activities:

- creating a new commercial mass of products of the fisheries industry (including those with high added value);

- creating an export-oriented commodity distribution infrastructure, creating a system for promoting and positioning products.

The first event provides for the implementation of projects for the construction and commissioning of large-capacity coastal plants for processing pollock, herring, and other fish species (investors are Fishing collective farm Noviy Mir JSC and Russkiy Mintay LLC). It is also planned to implement projects for the construction and commissioning of six processor trawlers with the length of over 105 meters for pollock 
and herring fishing (investor is Russian Fishery Company LLC). The construction of a plant for processing various types of high-capacity fish has been completed in Bolshoy Kamen (Fishing collective farm Noviy Mir JSC).

In the framework of the second event, since 2014, Far Eastern Auction Fish House JSC (Vladivostok) together with St. Petersburg Exchange JSC have been implementing a pilot project to create an electronic trading system for ABR products using exchange and electronic platforms. Thus, 51 enterprises are registered with the Exchange, including 11 foreign companies (Avarsky and Poplaukhina, 2015; Resolution of the Primorsky Krai Administration, 2012).

In December 2019, a new state program "Development of the Fisheries Industry of the Primorsky Territory for 2020-2027" was approved. Some changes were made to the document according to the reality of contemporary times, in particular, the subprogram "Development of Aquaculture (fish farming) in the Primorsky Territory" was added.

The new state program for 2020-2027 includes the following goals: 1) increasing the output of the fisheries industry in the Primorsky Territory 1.5 times by 2027, including products with high added value, due to 1.6 times increase in the catch volume of the ABR, and two times increase in production (cultivation) of aquaculture products; 2) strengthening the positions of coastal companies and products in the Russian and world markets; 3 ) ensuring the competitiveness of Russian fish products in domestic and foreign markets.

The export of fish products and other ABR in the Primorsky Territory according to the federal project "Export of Agribusiness Products" should reach USD 2 billion in value terms by 2024.

It should be noted that since January 1, 2020, the Department of Fisheries and Aquatic Bioresources has been changed by the Agency for Fisheries. The Agency for Fisheries of the Primorsky Territory is an executive body of the Primorsky Territory that carries out within its powers the state management in the field of fisheries and aquaculture (fish farming).

\section{THE SAKHALIN REGION}

The fisheries industry of the Sakhalin region ranks third in the FEFD in terms of the catch of ABR and production of fish and other aquatic products, and first in terms of the potential capacity of onshore processing industries (about 3 million tons per year).

As of 01.01.2020, the territory of the Sakhalin region hosts 937 enterprises engaged in the extraction and processing of $\mathrm{ABR}$, of which 215 enterprises have their processing facilities and, at the same time, are engaged in the fish and seafood capture, 39 enterprises are engaged in the reproduction of biological resources.

In 2019, the production of fish and other seafood in the region amounted to 655.7 thousand tons, which was by $12.5 \%$ less than that in 2018 . This was largely due to a decrease in the spawning of Pacific salmon. Enterprises of the region produce a fairly wide range of products, such as frozen fish, preserves, canned food, smoked, dried, cured, delicatessen, and technical products (feed flour). Production of fish and other products is on average more than 450 thousand tons per year, while exports amount to more than 300 thousand tons (Table 4). In 2019, fewer products were produced - 430.2 thousand tons, which amounted to $87.5 \%$ compared to the previous year due to a decrease in total production. 
Table 4. Production and exports of ABR in the Sakhalin region in 2013-2018

\begin{tabular}{lllllll}
\hline \multirow{2}{*}{ Indicators } & \multicolumn{7}{l}{ Years } \\
\cline { 2 - 6 } & 2013 & 2014 & 2015 & 2016 & 2017 & 2018 \\
\cline { 2 - 7 } Production, thousand tons & 489 & 456 & 494 & 501 & 462 & 492 \\
Exports, thousand tons & 284 & 276 & 314 & 330 & 360 & 346 \\
Proportion of exports, \% & 58 & 61 & 64 & 66 & 78 & 70 \\
\hline $\begin{array}{l}\text { Source: Compiled by the authors according to the Fisheries Agency of the Sakhalin Region (Savinov and Migunov, 2008; Federation Council of the Federal } \\
\text { Assembly of the Russian Federation, 2019) }\end{array}$
\end{tabular}

In value terms, exports in 2019 amounted to USD 819.6 million, in physical terms - to 296 thousand tons. The main share of exports was frozen fish, a significant part was also made up of crustaceans and shellfish. Exports were mainly to China, the Republic of Korea, and Japan.

In the Sakhalin region, like in other regions of Russia, the project "Export of Agribusiness Products" is being implemented, which is aimed at increasing exports of ABR. The share of the Sakhalin Region in the total volume of exports of agricultural products should be $15.7 \%$ or USD 1,338.2 million by 2024 . At that, the ABR should become the chief export.

The region has approved the state program "Development of the Fisheries Industry of the Sakhalin Region", whose terms of implementation are from 2014 to 2020. The program's purpose is to create conditions for the effective and sustainable functioning of the fisheries industry, fuller development of underutilized fisheries stocks, to develop aquaculture, to improve the competitiveness of fish products and other ABR produced in the Sakhalin region, as well as to increase the investment attractiveness of the industry. It should be noted that in recent years the investment activity in the fisheries sector has been growing, which is demonstrated by the implementation of various projects. Investments are directed to the acquisition of the fleet, the modernization of production and the acquisition of fixed assets, the construction of salmon breeding plants on the Sakhalin and the Kuril Islands (Vorozhbit, 2007; Official website of the Governor and Government of the Sakhalin Region, 2020).

In 2019, the enterprises of the fisheries industry implemented investment projects both at their own expense and budget funds. The main areas of investments in 2020 were as follows:

1. Creating production facilities for deep processing of fish products. For this purpose, comprehensive investment project of LLC Fish Factory Ostrovnoy was developed.

2. Constructing fish waste processing plants. South Kuril fish factory LLC implemented the investment project on the construction of a plant for the production of fishmeal and fish oil in Yuzhno-Kurilsk for RUB 1,083 million. Project financing was carried out at the expense of own funds - RUB 270.7 million, and borrowed funds of the Sakhalin Region Development Corporation JSC in the form of a loan for RUB 812 million ( $75 \%$ of the project amount).

3. The work in the area of development of commercial aquaculture was underway.

Much attention is paid to the development of logistics infrastructure. In the territory of the Korsakov seaport, it is planned to create a Logistics Center for Aquatic Biological Resources, which will allow solving the main task of accumulating, sorting, and storing fish products for subsequent shipment to the buyer, both to the domestic and foreign markets.

All the above indicates that the Far East has a huge potential for the production and export of ABR. A lot of work has been carried out in the country in recent years for its development. As part of the implementation of the federal project "Export of Agribusiness Products" in the FEFD, investment 
activities aimed at building a modern fishing fleet, developing port and processing infrastructure, as well as producing aquaculture as a promising area not only for export but also for marketing these products within the country, are being intensified.

\section{CONCLUSION}

The FEFD provides more than $65 \%$ of the total production of ABR in Russia, whose significant part is intended for export supplies. The high demand for ABR in international markets has for many years stimulated the export of this category of goods, often to the detriment of the domestic consumer. However, it should be noted that the Russian Federation exported mainly raw materials. Currently, Russia has recognized the need to increase the competitiveness of fish and other $A B R$, as well as to increase the production of high-value-added goods. This task is formulated in the federal project "Export of Agribusiness Products". The country has also adopted the "Strategy for Development of Agriculture and Fisheries of the Russian Federation through 2030", which defines the goals, objectives, and main development courses of the industry. At the regional level, many entities of the Russian Federation, including the FEFD, have also adopted relevant documents. However, for the successful implementation of the scheduled plans, it is necessary to eliminate the following existing problems:

- physical and moral deterioration of the fishing fleet, coastal port, and processing infrastructure;

- unsatisfactory dynamics of updating the logistics infrastructure, as well as specialized rolling stock, and lack of development of multimodal transport;

- insufficient level of state support for the fisheries industry, including fishing in remote areas of the Global Ocean and seas, and support for the development of commercial aquaculture (commercial fish farming);

- lack of highly qualified personnel.

In recent years, work to eliminate existing problems in the country's fisheries industry, including in the FEFD, has become more active. The state has prepared a set of measures to encourage the construction of a fishing fleet at domestic shipyards, such as investment quotas, auction quotas for crab fishing with the obligation to build ships, as well as subsidies for the construction of a small and medium-tonnage vessels. In 2019, a decree of the Russian government was issued, according to which up to $30 \%$ of the cost of manufacturing small and medium-tonnage vessels would be reimbursed. The FEFD is extensively involved in this activity.

In May 2019, Russia adopted a federal law (On Amendments to the Federal Law "On Fishing and Conservation of Aquatic Biological Resources" in terms of improving the procedure for allocating quotas for production (catch) of ABR), which provided for a new mechanism for allocating quotas; enterprises that had received quotas for crab fishing had to invest in the construction of crab vessels. Later, another proposal was made: to facilitate the maximum placement of orders for the construction of crab ships in the Far Eastern shipyards, it was necessary to use subsidies, i.e. $20 \%$ of the cost of purchasing crab ships built in the FEFD, was reimbursed to the winners of the auction. Based on the results of auctions in 2019, contracts were signed for the construction of 15 crabbers at the Far Eastern shipyards.

An important point in the development of the fishing industry of the FEFD is the focus on the production of high value-added products. This requires, first of all, the modernization of existing processing facilities and the construction of new ones. Currently, exports consist mainly of raw materials that are processed abroad and the added value is not generated by Russian producers. Therefore, it is important to increase the production of high value-added products. 
The production of aquaculture can become one of the industry's development drivers. According to experts, the Far East, especially the south part of the region, can produce millions of tons of aquaculture products annually, but until recently only a small part of the fishing area has been developed. Today, the situation is gradually changing. At the initiative of the Ministry for Development of the Russian Far East, a special electronic service has been designed, namely, a geoinformation system that allows selecting a free site for fisheries, which can be obtained through an auction. It is necessary to intensify work in this direction. China and Japan, which are very interested in the production of aquaculture products in the Far East, are ready to invest in the industry.

Another problem that needs to be solved is the lack of qualified personnel in the fisheries industry of the FEFD. It should be noted that for the entire Russian fisheries sector, the lack and turnover of qualified personnel remains a serious problem. Training of workforce which can provide rational use of raw materials base of the Russian fisheries, trouble-free operation of fishing vessels, the performance of coastal enterprises and organizations of the industry is a strategic objective of the educational complex of the Russian Federal Fisheries Agency. This issue is given great attention in the "Strategy for Development of Agriculture and Fisheries of the Russian Federation through 2030", a well as in regional industry development programs. Besides, at present, fishing companies are actively involved in solving this problem as employers, and, if necessary, complete training of personnel independently. Some fishing companies actively cooperate with specialized universities, concluding contracts, and accepting students for the intern program.

Thus, the FEFD is actively working to eliminate existing shortcomings, but despite the success in developing the fisheries industry and strengthening export potential, there are still several problems to be solved in the region.

\section{REFERENCES}

Avarsky, N. D. and Poplaukhina, A. Yu. (2015). Dinamika razvitiya i riski rybohozyajstvennogo kompleksa Rossii [Development dynamics and risks of the fisheries industry of Russia]. Risk Management in Agribusiness, 2, 6-16.

Federal law of the Russian Federation No. 164-FZ. (December 8, 2003). “Ob osnovah gosudarstvennogo regulirovaniya vneshnetorgovoj deyatel'nosti [On the fundamentals of state regulation of foreign trade activities]" (as amended on 13.07.2015). Retrieved from: https://rg.ru/2003/12/18/vneshtorg-dok.html

Federal law of the Russian Federation No. 63-FZ. (April 14, 1998). "O merah po zashchite ekonomicheskih interesov Rossijskoj Federacii pri osushchestvlenii vneshnej torgovli tovarami [On measures for Protection of Economic Interests of the Russian Federation in Carrying out Foreign Trade in Goods]" (as amended on 08.12.2003, as amended on 16.12.2004). Retrieved from: http://base.garant.ru/12111284/

Federation Council of the Federal Assembly of the Russian Federation. (July 6, 2019). Eksportnyj potencial agropromyshlennogo kompleksa Rossijskoj Federacii: problemy i perspektivy razvitiya [Export potential of the agro-industrial complex of the Russian Federation: Problems and development prospects]. Information and analytical materials of the meeting of the Board on Agriculture and Natural Resources at the Federation Council. Moscow.

Fishnews. (2020). Vlasti Kamchatki predstavili itogi razvitiya otrasli za 2019 god [The authorities of Kamchatka presented the results of the industry development for 2019]. Retrieved from: https://fishnews.ru/news/38548 
Fishretail. (2019). Eksport moreproduktov na Dal'nem Vostoke za 9 mesyacev 2019 goda vyros na 5.4\% do $1.2 \mathrm{mln}$ tonnes [Seafood exports in the Far East for 9 months of 2019 increased by $5.4 \%$ to 1.2 million tons]. Retrieved from: https://fishretail.ru/news/eksport-moreproduktov-na-dalnem-vostoke-za-401793

Ivanova, I. V. (2011). Problemy rybohozyajstvennogo kompleksa Kamchatskogo kraya [Problems of the fishing industry of the Kamchatka Territory]. Russian Entrepreneurship, 12 (9), 141-144.

KAM 24. (2019). Eksport ryby i moreproduktov s Kamchatki dostig pochti 800 millionov dollarov [Export of fish and seafood from Kamchatka reached almost 800 million dollars]. Retrieved from: https://www.kam24.ru/news/main/20190429/68106.html\#sthash.yVeKJjT2.dpuf

Kolonchin, K. V. (2019). Sovremennye problemy i perspektivy razvitiya rybopromyslovogo flota Rossii [Contemporary problems and development prospects of the fishing fleet of Russia]. Economy, Labor, Management in Agriculture, 8, 23-36.

Kolonchin, K. V., Seregin, S. N. and Gasanova, Kh. N. (2018). Stimulirovanie rossijskogo eksporta rybnoj produkcii [Stimulation of Russian export of fish products]. Economy, Labor, Management in Agriculture, 12, 117-129.

Kuban Agricultural Information and Consulting Center. (2019). Obzor rossijskogo i mirovogo rynka ryby na 25.01.2019 [Review of the Russian and world fish market for 25.01.2019]. Retrieved from: http://www.kaicc.ru/sites/default/files/1/\%D0\%9E\%D0\%91\%D0\%97\%D0\%9E\%D0\%A0\%20\%D0\%A0 \%D0\%AB\%D0\%9D\%D0\%9A\%D0\%90\%20\%D0\%A0\%D0\%AB\%D0\%91\%D0\%AB\%20\%D0\%9D\%D $\underline{0 \% 90 \% 2025.01 .2019 . \mathrm{pdf}}$

Medvedeva, N. A. (2019). Razvitie eksportnogo potenciala Rossii v agroprodovol'stvennoj sfere [Development of Russia's export potential in the agri-food sector]. Economy, Labor, Management in Agriculture, 9, 2-10.

Official website of the Government of Primorsky Krai. (2020). Obshchie itogi raboty rybohozyajstvennogo kompleksa Primorskogo kraya za 2019 god [General results of the performance of the Primorsky Territory fisheries industry for 2019]. Retrieved from: https://www.primorsky.ru/authorities/executive-agencies/departments/fishery/results.php

Official website of the Governor and Government of the Sakhalin Region. (2020). Rybopromyshlennyj kompleks [Fish industry complex]. Retrieved from: https://sakhalin.gov.ru/?id=159

Order of the Government of the Russian Federation No. 2798-r. (November 26, 2019). "Ob utverzhdenii Strategii razvitiya rybohozyajstvennogo kompleksa Rossijskoj Federacii na period do 2030 goda [On approval the Strategy for Development of Agriculture and Fisheries of the Russian Federation through 2030]". Retrieved from: http://publication.pravo.gov.ru/Document/View/0001201911280005

Paptsov, A. G., Ushachev, I. G., Altukhov, A. I., Arzhantsev, S. A., Bykov, G. Ye., Logacheva, O. V., Nechayev, V. I., Osinina, A. Yu., Pisareva, L. V., Semenova, Ye. I., Frolova, Ye. Yu., Cherkasova, O. V., Shelamova, N. A., Gasanova, Kh. N., Avdeyev, M. V., Maslova, V. V., Osipova, A. N., Zubkova, Yu. V., Medvedeva, N. A., Prokhorenko, O. S., ... Chekalin, V. S. (2020). Eksport produkcii APK Rossii: tendencii i razvitie [Export of agribusiness products of Russia: Trends and development]. Monograph. Moscow, Russia: Sam Poligrafist.

Public Council at the Federal Agency for fishery. (March 18, 2020). Itogi deyatel'nosti Federal'nogo agentstva po rybolovstvu v 2019 godu i zadachi na 2020 god [Performance results of the Federal Agency 
for Fisheries in 2019 and tasks for 2020]. Retrieved from: http://fishcom.ru/files/documents/ob agentstve/kollegiya/itogi kollegii 2019.pdf

Resolution of the Government of the Russian Federation No. 717. (July 14, 2012). "Ob utverzhdenii Gosudarstvennoy programmy razvitiya sel'skogo hozyajstva i regulirovaniya rynkov sel'skohozyajstvennoj produkcii, syr'ya i prodovol'stviya na 2013-2020 gody [On approval of the State Program on Development and Regulation of Farm Produce, Raw Materials and Foodstuffs Markets for 2013-2020]. Retrieved from: https://rg.ru/2012/08/07/selo-site-dok.html

Resolution of the Primorsky Krai Administration No. 389-pa. (December 7, 2012). "Ob utverzhdenii gosudarstvennoy programmy Primorskogo kraya "Razvitie rybohozyajstvennogo kompleksa Primorskogo kraya na 2013-2021 gody" [On approval of the state program of the Primorsky Territory "Development of the fisheries industry of the Primorsky Territory for 2013-2021"]" (as amended on 20.12.2019). Retrieved from: https://rg.ru/2014/09/29/primorie-post389-reg-dok.html

Ryzhkova, S. M., Kruchinina, V. M., Gasanova, Kh. N. and Zakharchenko, E. N. (2020). Proizvodstvo rybnoj produkcii i vodnyh bioresursov $\mathrm{v}$ sovremennoj Rossii [Production of fish products and aquatic bioresources in contemporary Russia]. Economy, Labor, Management in Agriculture, 1 (58), 96-104.

Savinov, Yu. A. and Migunov, A. Yu. (2008). Gosudarstvennaya finansovaya podderzhka eksporta v Rossii [State financial support of export in Russia]. Russian Foreign Economic Bulletin, 5, 30-37.

Sea News. (2019). Rossijskij eksport ryby vyros [Russian fish export has grown]. Retrieved from: https://seanews.ru/2019/03/14/ru-rossijskij-jeksport-ryby-sokratilsja/

Shelamova, N. A. (2020). Razvitie eksportnogo potenciala i infrastruktury rybolovstva Dal'nego Vostoka [Development of export potential and fishing infrastructure of the Far East]. Economics of Agriculture in Russia, 6, 86-90.

Ushachev, I. G., Maslova, V. V. and Chekalin, V. S. (2019a). Povyshenie eksportnogo potenciala APK na osnove innovacionnogo razvitiya [Increasing the export potential of the agribusiness based on innovative development]. The economy of Agricultural and Processing Enterprises, 10, 2-5.

Ushachev, I. G., Paptsov, A. G., Serkov, A. F., Maslova, V. V., Chekalin, V. S., Zaruk, N. F., Amosov, A. I., Avdeev, M. V., Kopasov, A. A., Kharina, M. V., Chepik, D. A., Orshanskaya, Yu. O., Maslov, I. I., Galkin, M. S. and Fedorenko, V. F. (2019b). Razvitie eksportnogo potenciala APK Rossii [Development of the export potential of the Russian agribusiness]: Monograph. Moscow: Russian Research Institute of Information and Technical and Economic Studies on Engineering and Technical Provision of AgroIndustrial Complex.

Vorozhbit, O. Yu. (2007). Konkurentosposobnost' rybnoj produkcii kak faktor ekonomicheskoj bezopasnosti [Competitiveness of fish products as a factor of economic security]. Russian Entrepreneurship, 8 (9), 119-123. 